\title{
Socio-Economic Conditions for Rural Development in Cholapur Block in Varanasi of Uttar Pradesh
}

\author{
Natasha $^{1 *}$, Pooja Pandey ${ }^{2}$, Suleman ${ }^{3}$ \\ ${ }^{1}$ Research scholar, Department of Geography, Banaras Hindu University Uttar Pradesh, India \\ ${ }^{2}$ Research scholar, G.B.Pant Social Science Institute, Prayagyraj Uttar Pradesh, India \\ ${ }^{3}$ Research scholar, Department of Geography, Banaras Hindu University Uttar Pradesh, India
}

DOI: $\underline{10.36348 / \text { sb.2020.v06i01.003 }}$ | Received: 08.01.2020 | Accepted: 15.01.2020 | Published: 29.01.2020

*Corresponding author: Natasha

\section{Abstract}

"Inequality is not just an issue between individuals, between classes, between regions. It's between urban and rural"Michael Jgnatieff. India is the country of diversity and uniqueness. Disparities and discrepancies are everywhere whether in policy making or policy implementation, economic or social characteristics in urban areas and rural areas. Rural percentage in total population was 82.7 percent in the year 1951 which lowers to 74.3 percent in 1991 and further down to 68.8 percent in 2011(census 2011). This shows a gradual declining trend in rural share in population, GDP and workforce through decades. Despite the Growing rate of urbanization, it is projected that the half of the country's population will be rural by 2050 . About 25.7 percent of total rural population lives below national poverty line (poverty estimates, planning commission report 2011). Rural societies in India suffer from disparities in terms of education, employment, gender biasness, land ownership and other assets. Thousands of people every year migrated in search for employment opportunities from rural to urban. For the eradication of these differences government tried the aid of rural development which includes the implementation of various life enhancing programmes. Uttar Pradesh has highest percentage of rural population in all states. Present study is all about rural development and the socio- economic condition of rural areas. Through which we got to know the actual condition of the cholapur block of Varanasi district. It also deals with the intensity of programmes launched by the government for development. Cholapur block is situated at 20 kilometres to the north of Varanasi city, it shows a pattern that how there will be great gap in urban and rural atmosphere.

Keywords: Disparity, Inequality, Poverty, Socio-Economic, Rural development.

Copyright @ 2020: This is an open-access article distributed under the terms of the Creative Commons Attribution license which permits unrestricted use, distribution, and reproduction in any medium for non-commercial use (NonCommercial, or CC-BY-NC) provided the original author and source are credited.

\section{INTRODUCTION}

India is the country of villages. Total population of India is 121 crore of which 83.3 crore people that is 68.84 percent of total population resides in villages [1].The proportion of rural population declined from 72.19 percent in 2001 to 68.84 percent to 2011. Uttar Pradesh is the particular state in which maximum number people that is 15.5 crore (18.62 percent) living in the rural areas [1]. In Varanasi district, about 56.56 percent of total population lives in rural areas which comprises 2,079,790. Of which $1.076,526$ were males and 1,003,264 were females respectively [1]. In rural areas of the district sex ratio is 932/1000 males. Child population comprise 15.08 percent of the total rural population. India is predominantly has an agrarian economy. According to agricultural census of India $2011,61.5$ percent of total dependent of agriculture for their livelihood. A purely agriculture country remains backward even in respect of agriculture [2]. Major of the rural employment depends on agriculture not because of its remunerative but because there are no alternative employment option. Agriculture is labour intensive employment with very low intensives. In 1970, concept of rural development evolves with a motive in increasing agriculture production. But now the concept of rural development had changed its perspectives. Rural development includes three dimensions, economic dimensions, social dimensions, political dimensions [3]. Development is a multi-dimensional concept involving reorganization and reorientation of entire economic and social system [4]. In general terms it means the constituting the positive change in present situation. According to Perroux, 
"development as the combination of mental and social changes among the population which decide to increase its real and global products, cumulatively and in sustainable manner". Development is a broad term which should be limited to mean economic development, economic welfare or material wellbeing; it broadly includes improvements in economic, social and political aspects of whole society like security, culture, social activities and political institutions [5]. It is a long participatory process of social change in the society whose objective is the material and social progress for the majority of the population through a better understanding of their environment [6].

Rural development generally refers to improving sustainable quality of lives and economic well-being of the people living especially the poor in isolated and sparsely populated area. The development of rural areas and agrarian societies has been always cantered in the mind of Indian policy makers since the advent of planning process in the country. The ultimate objective of rural development was the eradication of poverty and improving the quality of life of the rural masses. Theoretically it was to be focused on growth with equity but in reality the rural areas lagged behind in the process of economic growth that was remained concentrated in a few sectors and in certain regions of the country. After independence the pace of rural development was taken into account. Various programmes were launched especially in the field of agriculture sector like Intensive Agriculture District Programme [7], High Yielding Variety Programme [8], Drought Prone Area programme [9], Swarna Jayanti Gram Swarojgar Yojana [6], Mahatma Gandhi National Rural Employment Guarantee Act [11], National Rural Drinking Water Programme [10]. Besides the scientific and technological enhancements in the agricultural sector, situation is still worsening because these advancements are beyond the reach of small and marginal farmers. India is the land of small and marginal farmers, about 80 percent of the landholdings of individual farmers are below 1.5 acres which is far from viable equation (Krishnamurthy, AGM of NABARD). There is no better platform provided by government so that farmers can use it to make maximum benefit. Huge disparity between urban and rural societies raise serious question about developing the whole country or in contrast developing a sectional society in India.

Table-1: change in population and economically active persons in rural areas between 2004-05 and 2011-12

\begin{tabular}{|l|l|l|l|l|l|l|}
\hline \multirow{2}{*}{ Particulars } & \multicolumn{2}{|c|}{ Male (million) } & \multicolumn{2}{c|}{ Female (million) } & \multicolumn{2}{c|}{ Persons (million) } \\
\cline { 2 - 7 } & $\mathbf{2 0 0 4 - 0 5}$ & $\mathbf{2 0 1 1 - 1 2}$ & $\mathbf{2 0 0 4 - 0 5}$ & $\mathbf{2 0 1 1 - 1 2}$ & $\mathbf{2 0 0 4 - 0 5}$ & $\mathbf{2 0 1 1 - 1 2}$ \\
\hline Population & 401 & 432 & 379 & 410 & 780 & 842 \\
\hline LFPR (\%) & 56 & 55 & 33 & 25 & 45 & 41 \\
\hline Labour force & 223 & 239 & 126 & 104 & 349 & 342 \\
\hline Workforce & 219 & 235 & 124 & 102 & 343 & 336 \\
\hline Agriculture & 146 & 139 & 103 & 76 & 249 & 216 \\
\hline Cultivators & 93 & 92 & 67 & 49 & 160 & 141 \\
\hline Agri. labour & 53 & 48 & 37 & 27 & 89 & 75 \\
\hline Non-farm & 73 & 95 & 21 & 26 & 94 & 121 \\
\hline
\end{tabular}

Labour force participation rate (LFPR) is decreasing gradually. Male rural population increased by 31 million and the LFPR rate decreased by only one percent between 2004-05 and 2011-12. There is drastic decline in the contribution of labour force and in LFPR rate. In 2004-05 the LFPR rate was 33 percent which decreased to 25 percent in 2011-12. One of the reasons behind the fall in the female rural workforce contribution was the increased enrolment in education [12]. The LFPR rate of total rural population in 2004-05 was 45 percent which declined by 3 points to (41 percent) in 2011-12. There shows an increasing trend in Non-farm activities by all set of population from the year 2004-05 to 2011-12. Male rural population increased 22 million whereas female rural population increased by 5 million. Total rural population increased by 27 million in Non-farm contributions.

India categorized in world largest economies list, with the growth rate of 10 percent and GDP of
1,644 billion US dollars. Beside these positive aspects, two-third of people in India lives in poverty. According to World bank report, 1975 [14]" The rural development in general used to denote the actions and initiatives taken to improve the standard of living in non-urban neighbourhood and remote villages. Rural development is a strategy designed to improve the economic and social life of a specific group of peoplethe rural poor. It involves extending the benefits of development to the poorest among those who seek a livelihood in the rural areas". Socio-economic status is a composite measure of an individual's economic and sociological standing. It is a complex assessment measured in a variety of ways that account for a person's work experience and economic and social position in relation to others, based on income, education, and occupation [7]. Socio-economic status has been a powerful determinant of health; as a general rule, wealthy people tend to be in better health than other people of poorer status [13]. 


\section{STUDY AREA}

Cholapur is one of the eight developmental blocks of Varanasi district. Lies in the north eastern part of the district with latitude (250 34' 39', - 250 $\left.25^{\prime} 15^{\prime}, \mathrm{N}\right)$ longitude-(830 10'40', $\left.82057^{\prime} 7{ }^{\prime}, \mathrm{E}\right)$. It is bounded by Gomati River in north and Ganga River in the east. Cholapur extended to an area of 190.45 square kilometres out of 1535 square kilometre of Varanasi district. According to the census 2011, it has 35,046 households in 141 villages and four villages (Goppur first, Alamnagar, Hulsipur, Jagasipatti) are uninhabited. It holds total population of 238,945 of which 122,945 are male and 116,000 are females [1]. Population between the age group ( 0 to 6 years) are 36,561 of which male population is 19,419 and female population is $17,142[1]$. There are 146,400 literates in the block out of which 86,334 are males and 60,066 are females [1].

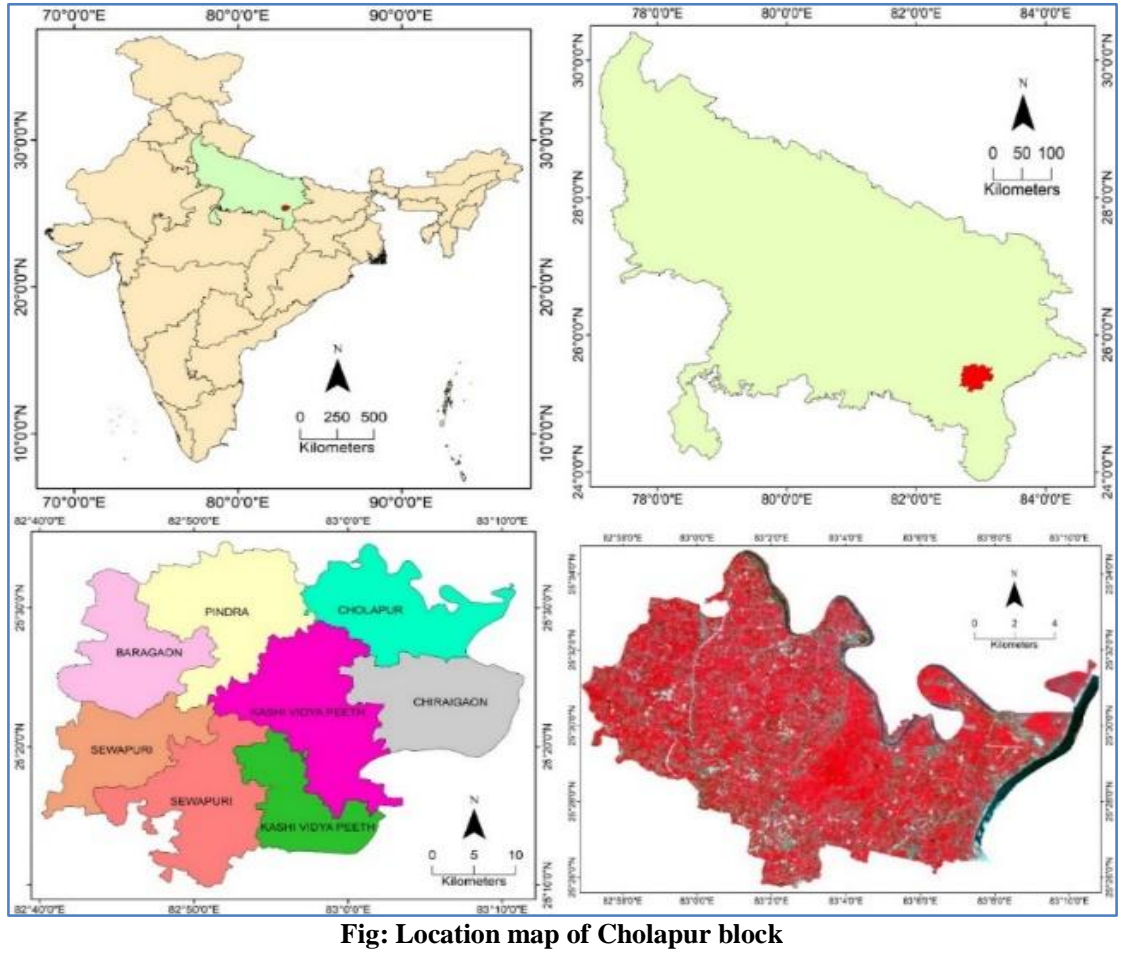

\section{DATA AND METHODOLOGY}

The methodology adopted here has addressed the issues related to the future considerations of village level planning and its sustainability. In order to complete the task, data both from primary and secondary sources are collected and generated. Field data collection, analysis and synthesis was done using statistic method with the help of SPSS and map produced with the help of arc GIS. Socio-economic questionnaire is used for the field survey. Through interview and participatory mode of observation data collected and situation is observed. A total of 400 samples were taken from all 141 villages on the basis of Yemen's formula (for sample size). Stratified sampling method is used on the basis of caste stratification.

\section{RESULT AND DISCUSSIONS}

\section{Socio-economic and demographic background}

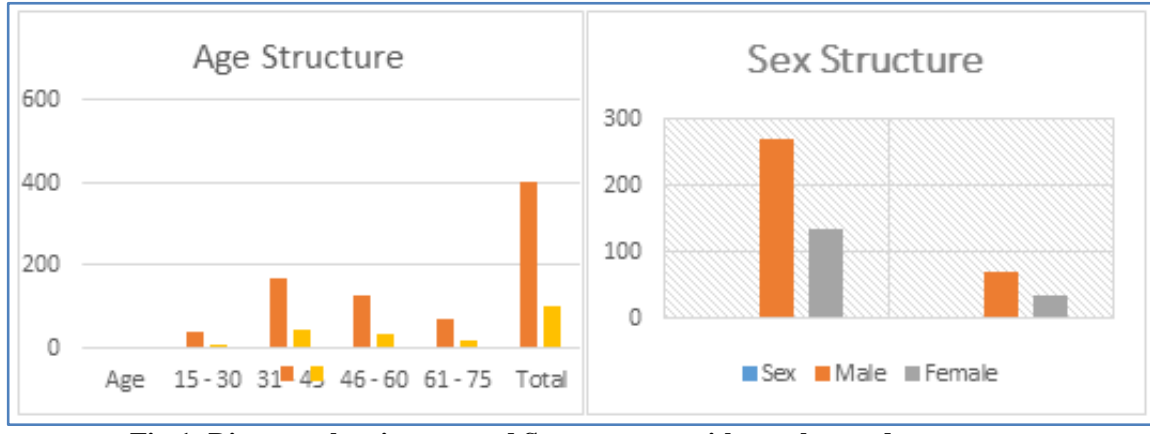

Fig-1: Diagram showing age and Sex structure with number and percentage 
Figure 1 illustrates the age and sex determinants among the respondents. Out of 400 samples, 268 were males which comprise of $67.0 \%$ and 132 i.e. $33.0 \%$ were females and number of women answering the survey belongs to the category of middle aged married women because women in the household are yet not allowed to participate in the conversation with the surveyors. Here it must be noted that, these women came forward for survey as their husband or any other male member were not present at home at the time of survey

\section{Religion and Caste}

As figure 2, remarks the distribution on the basis of religion and caste out of total respondent 97.8 percent were belong to Hindu community and only 9 percent respondent belong to Muslim community. This shows the distribution of Hindu majority village in the area. Villages are dominated by Hindu dwellers compared to Muslim. From the bottom level caste system holds a clutch on the societal categorization. From the above table, we came to know that 22 percent of the total respondent belongs to general community, 30.3 percent of the came from other backward community followed by 38.2 percent from SC community and 9.5 percent from ST community. OBC and SC population are more in block compared to ST population which are very less. In some of the villages ST community are not found.

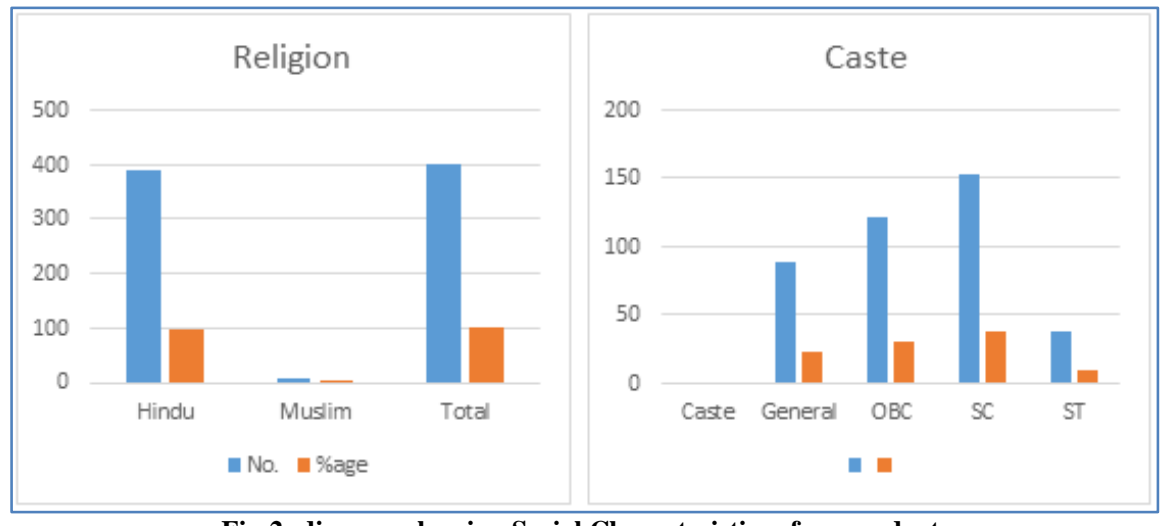

Fig-2: diagram showing Social Characteristics of respondents

\section{Family type and family size}

As figure 3 suggests the present scenario of family size and family type in the study area. A total of 251 that is 62.7 percent of the total respondent states that they live in joint family compared to 37.3 percent (149) of respondent living in nuclear family. This family shows that joint family concept still perceived in the rural Varanasi. A total of 119 respondent that i.e.
29.5 percent of the respondent states that they live in family of 3 to 5 persons. 59 percent of the respondent states that their family size is about 6 to 8 persons and 11.5 percent states that more than 8 persons living in the family. This pattern shows a concept of integrity of dependency ratio as well as unplanned family planning at the same time.

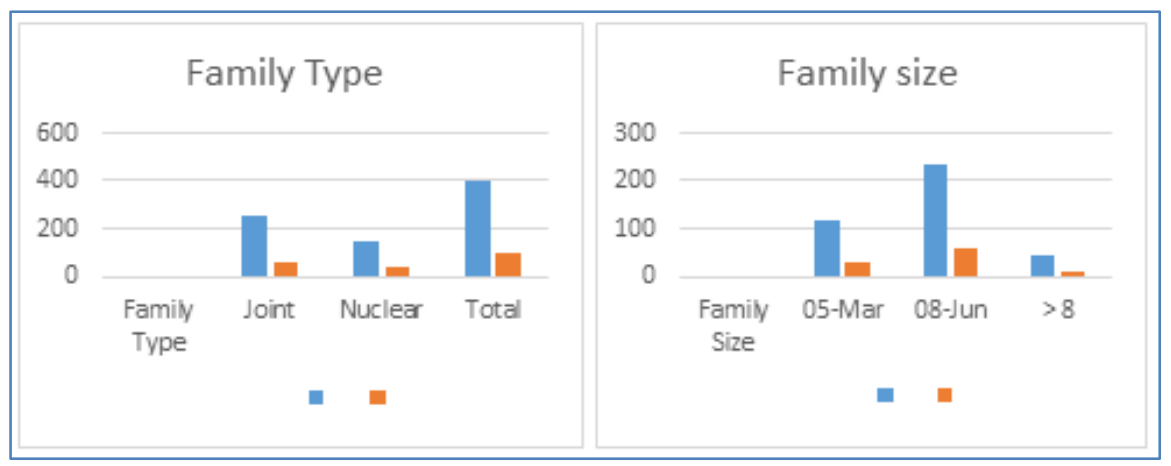

Fig-3: Diagram showing Family types and size with number and percentage

\section{Educational status}

As figure 4 states the educational status of the respondents, majority of the respondents were literates only 2.3 percent (9) respondents were illiterate. Among the literates 2.7 percent were high school passed or dropout followed by 18.5 percent of respondent who studied till $8^{\text {th }}$ standard or less. 18.2 percent were $12^{\text {th }}$ passed and 18.5 percent 2.8 percent, 1.0 percent were undergraduate, post graduate and professional degree holders. 11.7 percent of the respondent were attended only the primary classes and then dropout. 


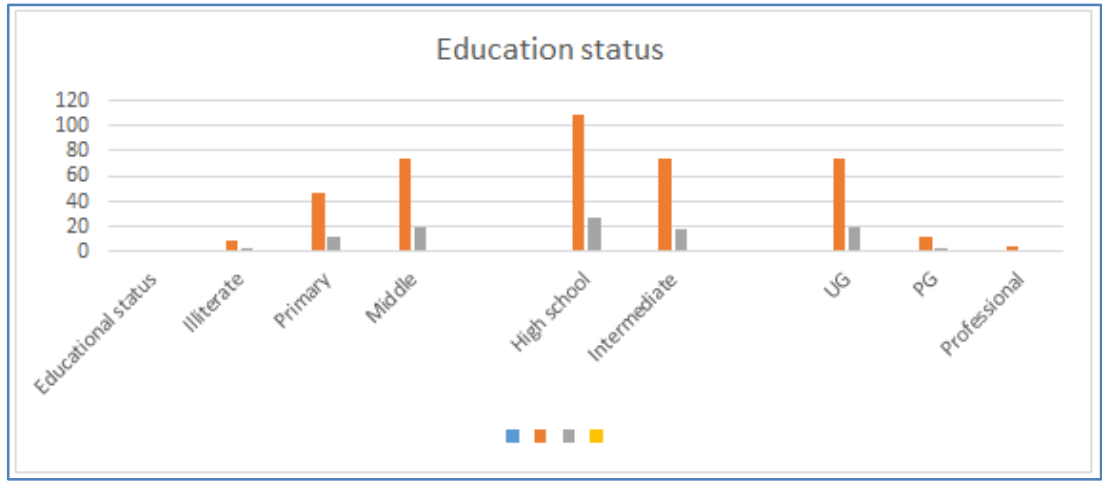

Fig-4: Diagram showing educational status with number and percentage

\section{Occupational structure}

Figure 5 elaborates a sense about the occupational structure of the families of the respondents. The observation based on the above table concludes that 27 percent of the total family have agriculture as the main source of income. 20.2 percent family earned their income as non-agricultural labour, followed by those families whose income is based on agriculture as well as service. Some of the families that is 11.3 percent shows that they are not wholly dependent on agriculture as the prime source of income, rather they adopt small business to run their families. 10.2 percent of the families depend on the wages as agricultural labour which are seasonal. Business is an upcoming mode of source of income in rural areas. About 8.3 percent families earned income only from small business. About 3.8 percent people indulged in business as well as service whether private or government. 3.2 percent work in private or government sector to earn their livelihood. Only 1.3 percent and 1.5 percent of the families depend either on remittances or earned as an artesian.

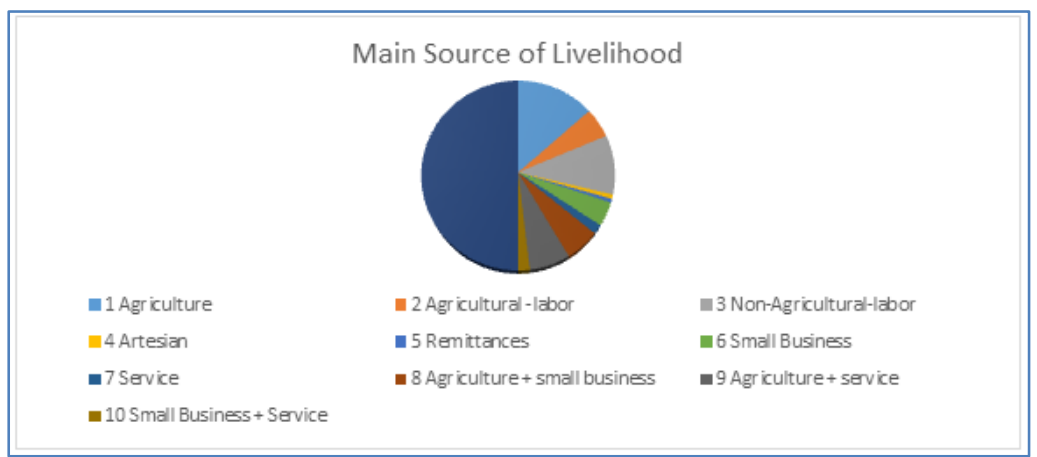

Fig-5: Diagram shows the main source of livelihood of villagers with number and percentage

\section{Monthly Income}

Average monthly per capita income is found to be maximum Rupees 4506.43 among general caste followed by 1916.38 and 1451.34 among OBC and SC respectively while it was minimum in 1308.07 among ST in below figure 6. Statistical F ratio signifies the fact that there is highly significant difference in average
MPCI among various caste group respondent family. But post hoc test clear the fact that the average MPCI was significantly more among general caste in comparison to OBC,SC,ST whereas no significant difference exists among the respondent belong to $\mathrm{OBC}$, $\mathrm{SC}$, and ST respectively.

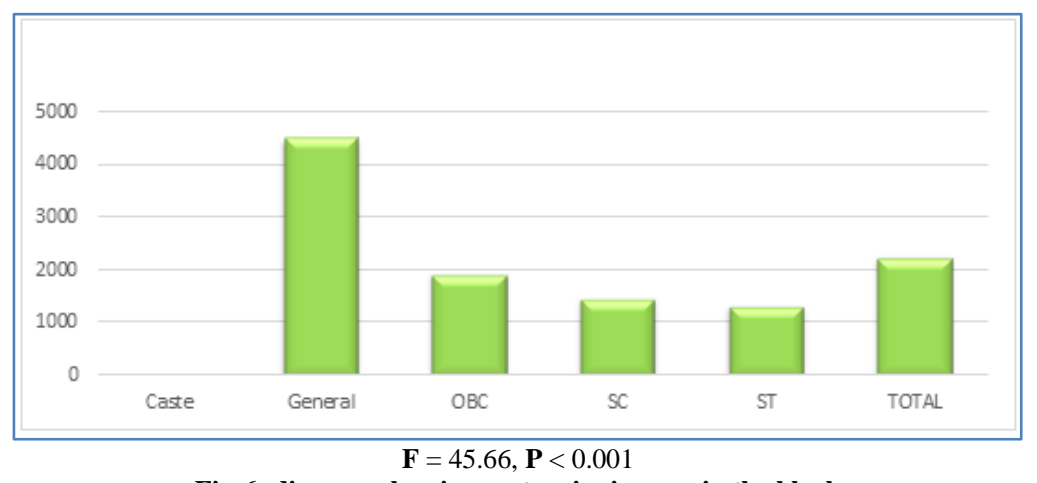

Fig-6: diagram showing caste-wise income in the block 


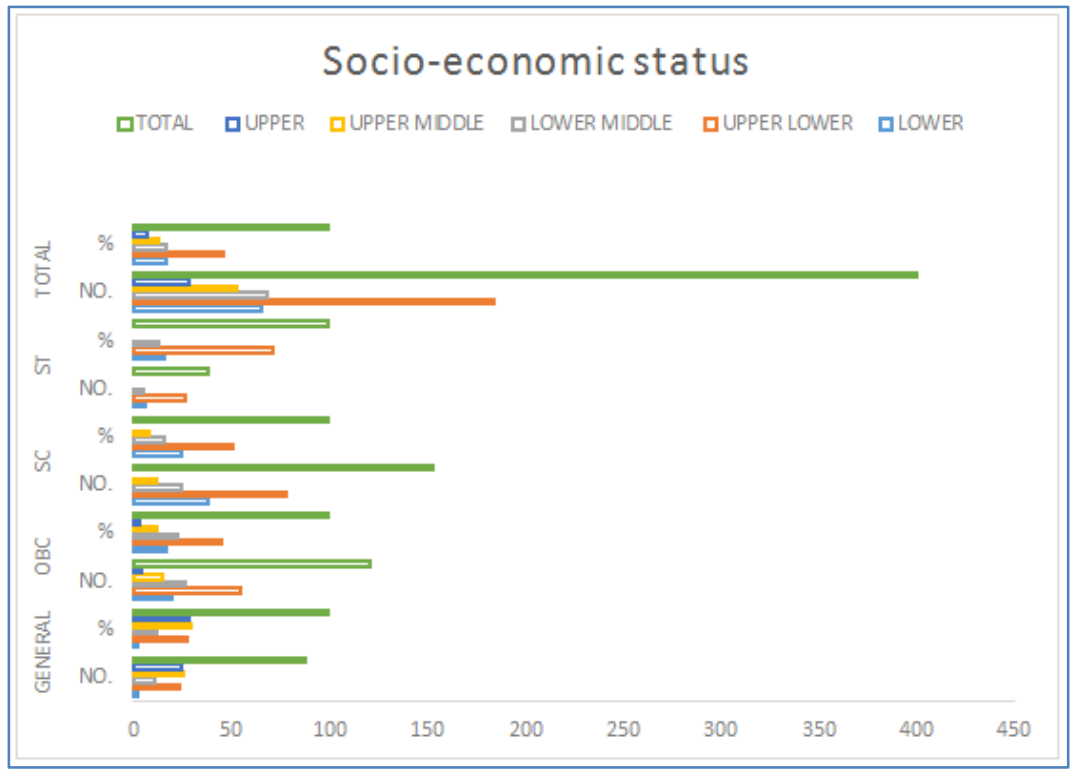

Fig-7: Diagram showing caste-wise economic status of the villagers in the block

\section{Type of house}

Figure 8 states that, 52.7 percent respondent have pucca houses while 32.5 percent of respondent have semi pucca houses. 13.8 percent have kuccha houses followed by 1 percent respondent having huts. This shows a pattern of having pucca houses more important than anything government helped people to build their own houses.

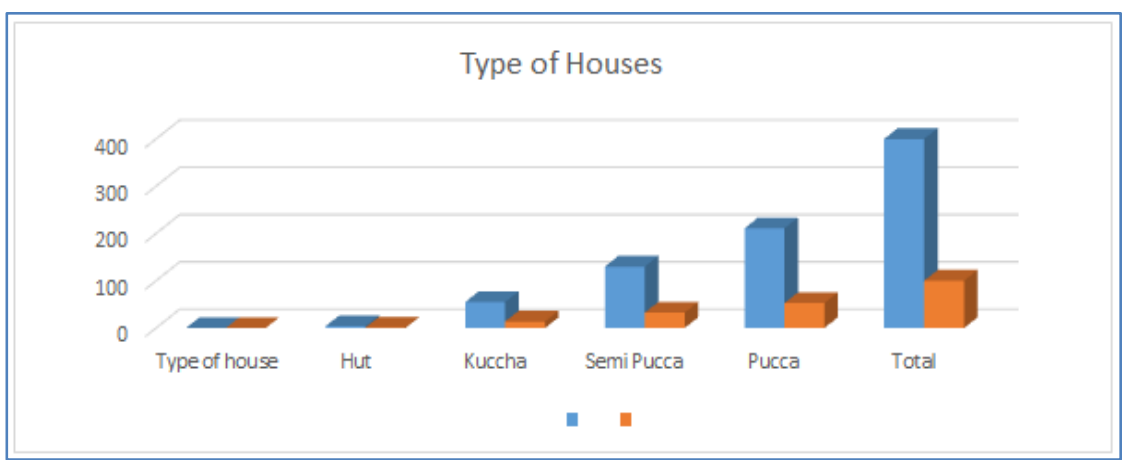

Fig-8: Diagram showing type of houses built in the village with number and percentage

\section{Type of fuel used for cooking}

Figure 9 suggests that 14.7 percent of respondent use only LPG connection. 6.2 percent and 0.5 percent of respondent use only dung cake and wood. Whereas 16.5 percent dung cake and wood, 35 percent use dung cake and LPG as per their comfort and availability. 103 respondents that is 25 percent out of total use all of the above mode of fuel for cooking purpose which is subject to accessibility and availability.

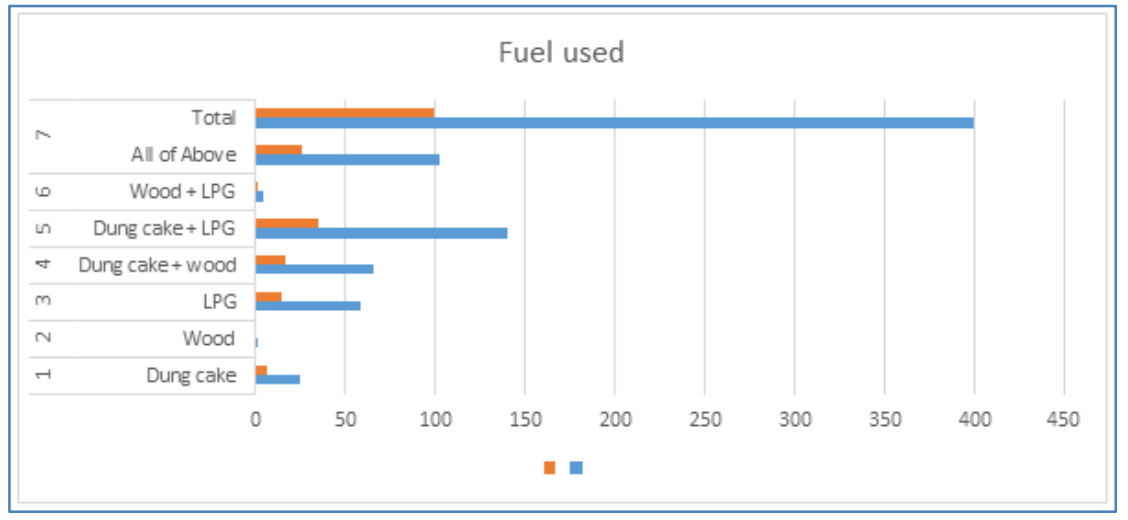

Fig-9: Diagram showing type of fuel used by villagers for cooking 


\section{Main source of drinking water}

\section{PERCENTAGE OF RESPONDENT USING DIFFERENT TYPES OF MAIN}

SOURCE OF DRINKING WATER

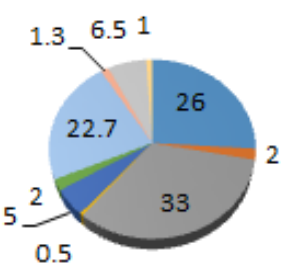

- OWN HAND PUMP

- OWN WELL

PUBLIC HAND PUMP

- PUBLIC WELL

- SHARED/GOVT. HAND PUMP

TAP WATER/PUMP

- OWN HAND PUMP+TAP

OWN WELL+ TAP

PUBLIC HANDPUMP + TAP

Fig-10: chart showing the major source of Drinking water of the villagers

Sanitation not only depends on the method and procedures of hygiene and disposal but also directly or indirectly depends on the source of drinking water. Cholapur block wholly lies in the basin area of Gomati and Ganga River, consequently, a total of 22.7 percent of the total respondent possess own hand pumps and taps followed by 33 percent of respondent using public hand pumps. 2 percent and of total respondent own well or have tap water.

\section{Main source lighting}

Figure 11 below shows the relation between main sources of light in the house to the caste distribution. A total of 29.5 percent of all have electricity connection in their home in which, 46.6 percent respondent of general category have the permanent power connection followed by 32.2 percent in OBC category and 18.3 percent and 5.3 percent of respondent in SC and ST category. About 2.5 percent respondent use kerosene lamp as the source of power in which 1.1 percent respondent belong to general category followed by 7.4 percent OBC category and 3.9 percent of ST category. At some circumstance respondent told of using more than one type of source of lightening due to the availability and accessibility. 36 percent of the total respondent use both kerosene and temporary electricity connection in which 9.1 percent belong to general category, 33.1 percent belong to OBC, 44.4 percent belong to SC community and 17.7 percent were from ST community.

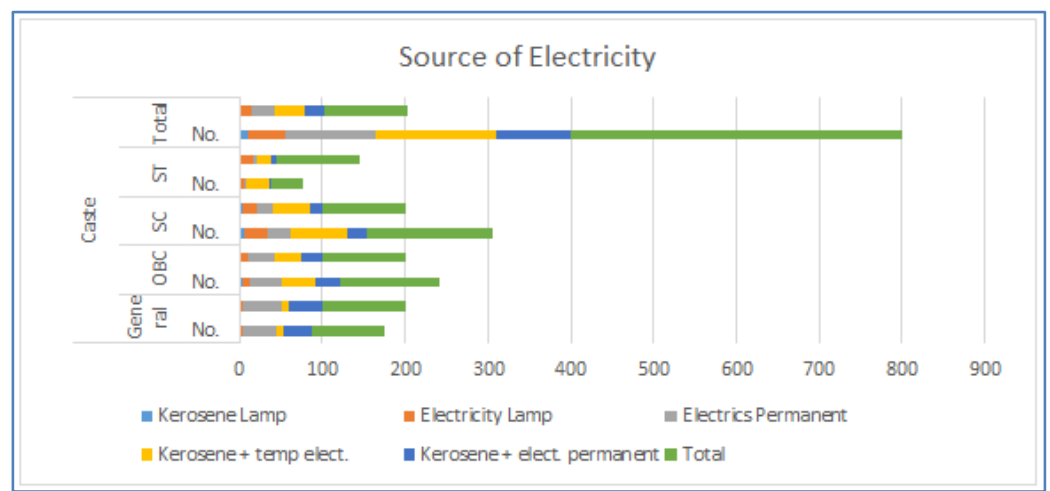

Fig-11: diagram showing the major source of power connection in the villages

\section{Toilet facility}

As the Graph states that 300 respondent out of total use toilet facility. Within premises number and percentage of respondents are 146(48.7\%) and outside the premises the number and percentage are as follows $154(51.3 \%) .100$ respondents that is 25 percent of total respondent states that they use shared or open area defecation. In which 61 percent use shared toilets whose condition are very poor and 35 percent practice open defecation system. Condition of cholapur block in terms of sanitation and other household facility like education and health care centres are not up to the mark.

\section{AVAILABILITY OF TOILET} FACILITY

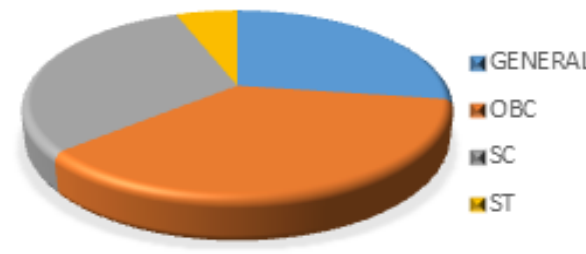

Fig-12: diagram showing the Caste-wise availability of toilet facility in the villages 


\section{Land Holdings}

As figure 13 states the distribution between the castes and presence of agricultural land. 157 respondents that is 76.2 percent out of the respondent agreed on the possession of agricultural land as the main source of livelihood. Out of which 67 respondent are of general category, 54 are of OBC category, 36 are of SC community. No ST category respondent states that they have their own agricultural land. About 23.8 percent of total respondent whose main source of livelihood is agriculture do not own land.7 respondent in SC community, 21 in OBC community, 17 in SC community and 4 respondent in general community said that they work in others land for livelihood.

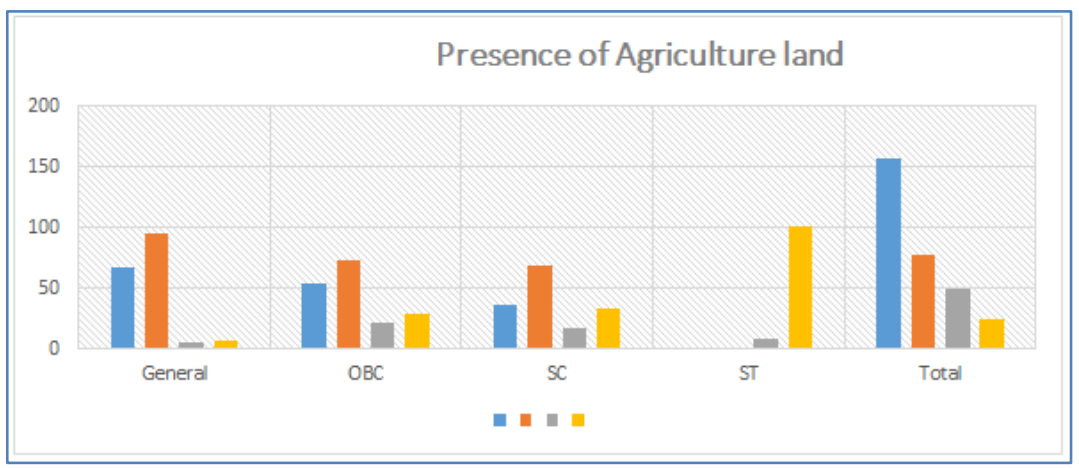

Fig-13: diagram showing the Caste-wise availability of Agricultural land in the villages

\section{Livestock possession}

Livestock possession is one of the major activity in the rural areas. The table discuss the caste wise livestock holding in the block. Four types of livestock are common they are cow, buffalo, goat, and ox. 63 percent of the general Respondent said that they have buffalo 70 percent of general respondent said they have cow, 3.8 percent said that they have goat. Cattle rearing are very common in villages. In OBC community 58.3 percent of respondent states that they have buffalo, 70.9 percent said they possess cow and 24.3 and only 1 percent respondent believes that they have goat and ox respectively. In SC community majority of the respondent that is 59 percent states that they have goat followed by 36 percent as cow and 33 percent as buffalo. As the table shows in ST community 95.7 percent of respondent have goat as livestock followed by 4.3 percent as cow and buffalo.

Table-2: possession of different type of livestock

\begin{tabular}{|c|c|c|c|c|c|c|c|c|c|c|}
\hline \multirow{3}{*}{ Buffalo } & \multicolumn{10}{|c|}{ Caste } \\
\hline & \multicolumn{2}{|c|}{ General } & \multicolumn{2}{|c|}{ OBC } & \multicolumn{2}{|l|}{ SC } & \multicolumn{2}{|l|}{ ST } & \multicolumn{2}{|c|}{ Total } \\
\hline & No. & $\%$ & No. & $\%$ & No. & $\%$ & No. & $\%$ & No. & $\%$ \\
\hline Yes & 51 & 63.7 & 60 & 58.3 & 33 & 31.4 & 1 & 4.3 & 145 & 46.6 \\
\hline No & 29 & 36.3 & 43 & 41.7 & 72 & 68.6 & 22 & 95.7 & 166 & 53.4 \\
\hline Total & 80 & 100.0 & 103 & 100.0 & 105 & 100.0 & 23 & 100.0 & 311 & 100.0 \\
\hline \multicolumn{11}{|l|}{ Cow } \\
\hline Yes & 70 & 81.5 & 73 & 70.9 & 36 & 34.3 & 1 & 4.3 & 180 & 57.9 \\
\hline No & 10 & 12.5 & 30 & 29.1 & 69 & 65.7 & 22 & 95.7 & 131 & 42.1 \\
\hline \multicolumn{11}{|l|}{ OX } \\
\hline Yes & 3 & 3.8 & 1 & 1.0 & 1 & 1.0 & 0 & 0.0 & 5 & 1.6 \\
\hline No & 77 & 96.3 & 102 & 99.0 & 104 & 99.0 & 23 & 100.0 & 306 & 98.4 \\
\hline \multicolumn{11}{|l|}{ Goat } \\
\hline Yes & 3 & 3.8 & 25 & 24.3 & 62 & 59.0 & 22 & 95.7 & 112 & 36.0 \\
\hline No & 77 & 96.2 & 78 & 75.7 & 43 & 41.0 & 1 & 4.3 & 199 & 64.0 \\
\hline
\end{tabular}

\section{SUMMARY AND CONCLUSIONS}

The study gave an inside view of rural societal structure and its nature. There was a lack of social mobility among the younger age group of women and they were expected to stay in home and take care of the household. It applies to both married and unmarried young women with in age group 16-35 years. Majority of the respondent were male aged between 31 to 45 years. The caste and religion are important aspects of the village society and it was found that all most all the respondents were Hindu and only nine respondents were found to be Muslim. No other religious group were found in the villages of Cholapur block. Similarly majority of the respondents were in SC and OBC category. It was also found that most of the respondents were literate. It was due to the participation of younger age male respondent in the survey. The future looks promising as most of the women understood the value of education and were very much interested towards educating their girl child. The family structure in rural 
villages was quite traditional with majority of the respondents having joint family and a family size of 610 members. To classify the respondents based on their socio economic status, updated B.G Prasad socio economic scale 2017 was used. According to the scale, the respondents were classified into five categories as, lower, upper lower, lower middle, upper middle and upper category. It was found that, majority of the respondents $(53.8 \%)$ were from upper lower category having monthly per capita income (MCPI) 938-1875 rupees. Average monthly per capita income is found to be maximum Rupees 4506.43 among general caste followed by 1916.38 and 1451.34 among OBC and SC respectively while it was minimum in 1308.07 among ST. It shows a very low income trend in rural families as most of the population in rural areas are engaged in agricultural and allied activities such as labourers which does not provide much income. Most of the families owned milch animals and were having their own home and majority had land of their own. This study shows the backward picture of the rural villages of the Cholapur block of Varanasi. Though numerous development programmes were being carried out in the district, due to lack of proper implementation and coordination among the implementing agencies, the rural poor beneficiaries was not getting the meant benefits. There is a strong need of transparency in the system to fight corruption to ensure the rural poor get maximum benefits.

\section{REFERENCES}

1. District Census Handbook, Census of India, 2011

2. Annual Reports of Ministry of Women and Child Development, Ministry of Social Empowerment and Justice, Ministry of Tribal Affairs and Ministry of Minority Affairs Selected Educational Statistics (2003-04).

3. Sarabhu, vijay kumar. (2018). "rural development in india- a way forward.

4. Todaro, G. J., De Larco, J. E., Fryling, C., Johnson, P. A., \& Sporn, M. B. (1981). Transforming growth factors (TGFs): properties and possible mechanisms of action. Journal of supramolecular structure and cellular biochemistry, 15(3), 287301.

5. Ravallion, M., Datt, G., \& Van De Walle, D. (1991). Quantifying absolute poverty in the developing world. Review of Income and Wealth, 37(4), 345-361.

6. Jordan, B. (1999). Begging: The global context and international comparisons. Begging questions: Street-level economic activity and social policy failure, 43-62.

7. Linda. Winters, A., Gary, D. (2010). Socioeconomic status. brocklehurst textbook of geriatric medicine and gerontology.

8. Hossain, S.A., \& Alam, M.A. (2016). SocioEconomic Status of the Street Children in Bangladesh. International Journal of Social Work, 3(1): $42-49$

9. Macdonald, A.M. (1972). Chambers Twentieth Century Dictionary, Chambers, Edinburgh.

10. Rao, D.C. (1978). "Economic Growth and Equity in the Republic of Korea", World Development, 6(3), 383-396.

11. Ravallion, M., \& Datt, G. (2002). Why has economic growth been more pro-poor in some states of India than others?. Journal of development economics, 68(2), 381-400.

12. Rai, R. (2000). Human Rights: U N Initiatives, Delhi: Authors Press, Delhi. Press note on Poverty Estimates 2011-12, July 2013, Planning commission, GOI

13. Shankar. (2013). "Socio Economic Conditions of Pachamalai Tribes". Cognitive Discourses International Multidisciplinary Journal, 1(1), 112118.

14. World Bank. (2003). Global Economic Prospects, Investing to Unlock Global Opportunities, Oxford University Press.

15. World Bank. (1990). World Development Report: Poverty and Development, Oxford University Press Washington DC. 